\title{
Earnings Management Through Deferred Taxes Recognized Under IAS 12: Evidence From Pakistan
}

\author{
Abdul Rafay* and Mobeen Ajmal ${ }^{* *}$
}

\begin{abstract}
This study examines earnings management through deferred taxes calculated under the IAS 12 and its impact on firm valuation. The literature finds that book-tax nonconformity leads to better earning quality and a greater association between earnings and future expected cash flows. Given that Pakistan is a pioneering implementer of the International Financial Reporting Standards, our hypothesis is that the components of deferred tax disclosed under the IAS 12 provide value-relevant information to equity investors. We divide deferred tax components into three categories: those arising from (i) operational activities, (ii) investing activities, and (iii) financing activities. These are subdivided to ensure that no value-relevant component is aggregated with a nonvalue-relevant component, which might otherwise lead to an information slack. Our sample includes data on shariah-compliant companies listed on the Karachi Meezan Index (KMI-30). We find that deferred tax line items in firms' balance sheets are reflected in market prices. Investors also tend to treat deferred tax line items (arising from operating, financing, and investing activities) differently. Furthermore, the value relevance is dissimilar for different components of deferred tax. Investors are wary of deferred tax assets and liabilities when pricing and are likely to penalize firms with a higher deferred tax position.
\end{abstract}

Keywords: Deferred tax, earnings, IFRS, IAS 12.

JEL classification: H22, H25, M410.

\section{Introduction}

Over the years, the position of deferred taxes has increased as fairvalue accounting takes precedence over cash-basis accounting (Poterba, Rao, \& Seidman, 2007), which results in a net increase in book-tax nonconformity. Pakistani firms report their net deferred tax position in their financial and related disclosures. The aim of this study is to analyze whether investors find these disclosures value-relevant.

\footnotetext{
* Associate professor of finance and accounting, University of Management and Technology, Lahore.

${ }^{* *}$ Lecturer in finance, University of Management and Technology, Lahore.
} 
Although we find that deferred taxes are value-relevant, investors tend to penalize firms reporting a deferred tax position: deferred tax liabilities (DTL) are treated as real liabilities while deferred tax assets (DTA) are treated as a negative asset class. This is because taxes generally have a negative connotation and deferred taxes are often misunderstood. The European Financial Reporting Advisory Group (EFRAG) points out that many users and preparers question the usability, understandability, and incremental value of decision-making under the International Accounting Standard (IAS) 12, arguing that it is difficult and costly to apply (EFRAG, n.d.). There is also a consensus that deferred tax notes and values are treated as a black box: most practitioners do not know how to use it, most stock analysts do not understand it (Carnahan \& Novack, 2002), most lenders ignore it, and a few reverse the deferred tax and use it as equity (Amir \& Sougiannis, 1999).

With increasing convergence toward the International Financial Reporting Standards (IFRS), many firms will have to report their deferred taxes, which will increase their costs as the IAS/IFRS entail extensive financial reporting requirements. In such an environment, it is necessary to document the value-relevance/irrelevance of deferred taxes for investors. Standard setters can use these findings to assess the usefulness of current IAS 12 reporting and disclosure requirements. Moreover, they should move toward a common deferred tax disclosure language or else investors are likely to continue discounting firms with a deferred tax position. Finally, deferred tax research on IFRS-based data is rare as most studies use data based on the Generally Accepted Accounting Principles (GAAP). Such research is, therefore, of common international interest.

\section{Deferred Taxes: A Brief Overview}

The tax payable for any company is calculated by multiplying its taxable income by the statutory corporate tax rate(s) devised by the federal government through legislation. A company's taxable income includes all its earnings of the tax year less permanent tax differences. This depends on whether the taxable income is charged under a presumptive tax regime or if it has a tax rate different from the corporate tax rate. The tax laws simply stipulate a methodology for computing taxable income and tax payable. However, since they account for both the fiscal and policy functions of the income tax statute, accounting personnel and tax authorities may calculate different taxable incomes (Chambers, 1968). 
Permanent taxable differences arise due to the different treatment suggested by IAS 12 and the tax authorities for components of income and expenses. For example, any expenditure classified as a fine or penalty for the violation of any law, rule, or obligation cannot be deducted when calculating income under the head "income from business," although the IAS 12 treats such items as expenditure. Similarly, dividend income, which is a part of book income, is not included in taxable income and instead is taxed as a separate block of income. Such permanent differences accrue and are reflected in the firm's accounting earnings, but they do not give rise to DTA or DTL.

Temporary tax differences arise when the IAS 12 and the rulings of the tax authorities diverge on recognizing a component of income or expenses. For example, under the matching principle, compensated absences are treated as an expense for the year to which they relate even though the payment is made in the next period. Since the tax authorities require the minimization of assumptions and ask for tax payments that are cash-based more than accruals-based, compensated absences are not treated as an expense until they are paid for. These differences give rise to current tax expenses as opposed to the total tax expenses of a particular year; current tax expenses represent that portion of total tax expenses that need to be filed as part of the current year's tax return.

The disparity between a company's total tax expenses and current tax expenses arising from temporary tax differences is known as deferred tax expense. The concept of deferred tax is notional as no taxable person is allowed to defer his/her tax payments. The inter-period tax allocation arises only due to differences in reporting as a result of the matching principle; it recognizes the tax consequences of an item in the same financial period as the item itself (Chludek, 2011).

Many balance sheet and income statement line items give rise to deferred tax expenses. The IFRS allow the use of the "liability method" to recognize deferred taxes. DTA are the historical sum of all temporary differences where the accumulated current tax expense exceeds the accumulated total tax expense reported in the firm's books. This implies that the firm has paid more tax than it should and is owed future tax relief, indicating a future decrease in tax-related cash flows. The amount realized is to the extent that cash inflows are probable. On the other hand, DTL imply that the firm has not yet paid all the taxes due on income as indicated by the IAS 12 and, therefore, will have increased future cash outflows with respect to taxes. 


\section{The Earnings Impact of Deferred Taxes}

Book-tax differences may reflect earnings management as large book-to-tax differences are correlated with a lower earnings-return relationship (Joos, Pratt, \& Young, 2002). Similarly, for years in which firms show a small increase in earnings per share (EPS), their deferred tax expenses are larger than for years in which there is a small decrease in EPS (Phillips, Pincus, \& Rego, 2003). These studies indicate that deferred taxes are a source of opportunistic earnings management, which, as Hanlon (2005) suggests, occurs because the accounting rules allow managers more discretion than tax authorities. The decrease in the amount of tax paid in cash-through the creation of DTL-results in a decrease in the amount of current explicit tax and thus, as per Hanlon and Heitzman (2010), can be classified as tax avoidance. Benign tax avoidance strategies increase the value of a firm (Brown, Drake, \& Martin, 2013) when investors perceive greater value addition from decreasing tax expenses through low-risk methods compared to aggressive tax reduction strategies (Hanlon \& Slemrod, 2009).

Deferred taxes are also a source of real increases in earning potential. Narasimhan and Harisha (2006) point out that deferring taxes is a free-of-cost source of funds. A decrease in the effective tax rate through the creation of DTL is positively correlated with the firm's future earnings (Schmidt, 2006). Givoly and Hayn (1992) note that decreases in DTL are treated as decreases in actual liabilities and as increases in share prices. Amir and Sougiannis (1999) report similar findings in that DTA are the result of carry-forward credits and treated as real assets by investors.

The value-relevance of deferred taxes depends on the timing of their reversal. Partial deferred taxes are more value-relevant because they capture only those DTL that will reverse in the short term (Wong, Wong, \& Naiker, 2011), while many other DTL do not result in a cash outflow (Beechy, 1983). For instance, a growing company with continuous investment in fixed assets will have continuous tax savings annually (Davidson, 1958), thus ensuring that the DTL do not reverse (Livingstone, 1967); investors find such liabilities to be a misnomer and regard them as a portion of equity (Wolk, Tearney, \& Dodd, 2001).

On the other hand, Sansing (1998) suggests that DTL are real liabilities the value of which does not depend on the timing of reversal. The fair value of such a liability is at a discount to the book value, but the discount rate is not time-dependent. The study also finds that the discount 
rate is proportional to the rate at which the liability is realized and to the sum of the firm's cost of capital and deferred tax reduction rate.

Guenther and Sansing (2000) report similar results for DTA and suggest that investors understand that the book value of DTL resulting from depreciation is undiscounted. The value is not equal to the present value of future deferred tax expenses primarily because the timing of the reversal is irrelevant; moreover, their value is zero if they never reverse (Stickney, 1993). However, the timing of the reversal is important for those deferred tax items that reverse simultaneously with a cash outflow (Sansing \& Guenther, 2003). These findings indicate that different components of deferred taxes are valued differently. Differentiation with respect to the value of the level of deferred taxes and the rate of reversal can also affect the valuation of the firm.

Amir, Kirschenheiter, and Willard (1997) support these findings, noting that different components of DTA and DTL affect firm valuation differently. Similar to restructuring charges, which are expected to reverse in subsequent periods, DTA are more value-relevant and thus have higher coefficients, while items such as employee benefits, which adjust slowly, are less value-relevant and have smaller coefficients. DTA related to unabsorbed losses have insignificant coefficients, indicating that they are not value-relevant: investors do not, therefore, expect to utilize these assets. DTL are similar to depreciation expenses in that their coefficients are small.

Most studies focus on the value-relevance of deferred taxes to investors. Some, such as Lev and Nissim (2004), conclude that there is no relationship between deferred tax expenses and the annual rate of return. Similarly, Chen and Schoderbek (2000) find evidence that analysts do not include deferred tax information in their earnings forecasts.

\section{Model Development}

We use Feltham and Ohlson's (1995) framework, which establishes the market price of equity $(\mathrm{P})$ as a linear function of net financial assets (NFA), current net operating assets (NOA), and internally unrecorded goodwill. Abnormal operating earnings (AOE) are used as a proxy for unrecorded goodwill. Net DTA are considered a separate asset class on the basis that net deferred taxes contribute significantly to measuring unrecorded goodwill. Goodwill calculations vary with the existence of deferred taxes: the sooner DTA (DTL) reverse, the more (less) goodwill is available through the adjustment of the present value of deferrals. It is also 
implied that the classification of deferred taxes as operating assets, financial assets, or shareholder equity affects the valuation of AOE.

Amir et al. (1997) relate the market price of equity to NOA, NFA, current AOE, and net deferred taxes (DT) in period $t$ as follows:

$$
P_{t}=\alpha+\beta_{1} N O A_{t}+\beta_{2} N F A_{t}+\beta_{3} A O E_{t}+\beta_{4} D T_{t}+\varepsilon_{t}
$$

Given that firms differ in terms of earnings persistence, Amir et al. (1997) add lagged abnormal operating earnings (LAOE) to equation (1) above, which yields:

$$
P_{t}=\alpha+\beta_{1} N O A_{t}+\beta_{2} N F A_{t}+\beta_{3} A O E_{t}+\beta_{4} D T_{t}+\beta_{5} L A O E_{t}+\varepsilon_{t}(2)
$$

In the case of unbiased accounting, the coefficient of NFA, $\beta_{2}$, should be 1 . However, since the IFRS adopt a conservative accounting approach, $\beta_{2}$ should be greater than 1 . NOA should be valued at more than its book value, implying that $\beta_{1}$ is positive and large. The coefficient of $\mathrm{AOE}, \beta_{3}$, and LAOE, $\beta_{5}$, should be equal to 0 if there is no persistence. The coefficient of DT, $\beta_{4}$, will depend on the expectation of reversal: greater reversal in the next period implies a larger beta. Its sign should be similar to that of NFA.

We capture the expected reversal of different deferred tax line items by using four different classification systems. In classification 1 , we add both components of net DT, i.e., DTA and DTL, to the regression equation. In classification 2, we separate DT into the most commonly recurring line items in a deferred tax disclosure, i.e., deferred taxes from accelerated depreciation, staff gratuity, provision for current assets, and unabsorbed tax losses and credit along with a net category for all other deferred taxes. Classification 3 is based on the nature of the activity-operating, financing, or investing-that generated the deferred tax. Classification 4 clubs together deferred taxes based on common traits and comprises the following categories: (i) depreciation and amortization, (ii) revaluation, (iii) deferred costs, (iv) human resources, (v) liabilities, (vi) taxes, and (vii) longterm investments. The results are estimated by the following equation:

$$
P_{t}=\alpha+\beta_{1} N O A_{t}+\beta_{2} N F A_{t}+\beta_{3} A O E_{t}+\sum_{t=1}^{n} \delta_{i t} D T C_{i t}+\varepsilon_{t}
$$


where $n$ equals 2 (classification 1), 5 (classification 2), 3 (classification 3), or 7 (classification 4) depending on the classification system and $D T C_{i t}$ represents the $i$ th component of deferred taxes in year $t$.

\section{Sample}

Our sample includes all companies currently listed on the Karachi Meezan Index (KMI-30), which measures the performance of shariahcompliant companies in Pakistan using free-float market capitalization. The data are drawn from the financial statements of these companies, based on two criteria: (i) each company's balance sheet should report its DT position and (ii) the notes to the financials should report both the DTA and DTL and their components. Based on these, the sample excludes companies such as HUBCO and Pakgen (Pvt.) Limited, both of which are tax-exempt. We have not used the Karachi Stock Exchange-30 because the index includes financial institutions for which it is difficult to differentiate between financial assets and operating assets.

Data on stock prices and betas are taken from Bloomberg; data on the treasury rate are from the State Bank of Pakistan's website. Firm-years for which financial data are not available have been dropped. No financial statement for Sui Northern Gas Pipelines Limited was available for 2013, while Engro Foods Limited did not start trading until 2010. Thus, after eliminating these, we obtain deferred tax data for 136 firm-years from 2009 to 2013. Once the LAOE has been determined, we are left with 108 firmyear observations (Table 1).

Table 1: Pooled sample

\begin{tabular}{lc}
\hline Firm years in KMI-30, 2009-13 & 150 \\
Tax-exempt firms & $(10)$ \\
Missing observations & $(4)$ \\
Total observations before LAOE & 136 \\
Lagged LAOE & $(30)$ \\
Total observations & 108 \\
\hline
\end{tabular}

Source: Authors' calculations.

The market value of equity at the fiscal year-end is calculated using the market value of equity per share. Data on the sample firms' financial assets and liabilities are taken from their respective risk management notes (reporting these data is compulsory under the IFRS). NOA is obtained by 
subtracting financial assets and DTA from total assets; net operating liabilities are obtained by subtracting financial liabilities and DTL from total equity and liabilities. All assets are taken as positive numbers and all liabilities as negative numbers.

Operating income is taken as the firm's earnings before interest, taxes, and expenses for extraordinary items. Abnormal after-tax operating earnings are calculated as the operating income minus the previous period's NOA multiplied by the cost of capital (taken as the weighted average cost of capital). The return on stocks is obtained using the capital asset pricing model and the return on debt is calculated by dividing the interest expense by the interest-bearing debt. To ensure that the regressions are not biased due to the size effect of idiosyncratic companies, we adjust all independent and dependent variables by the number of shares outstanding.

\section{Results}

The average market value per share for the firms in the sample is PRs 121.69 (Table 2). The average NOA is about PRs 106.60 or roughly 87 percent of the firm's market value. The average NFA is negative, indicating that, even for shariah-compliant securities, financial liabilities exceed financial assets and tax-deductible debt is used to finance operations. However, in line with shariah regulations, firms' average net financial liabilities represent only 18 percent of their market value. Average net DT represents only 1 percent of the market value, while for most firms DTL is greater than DTA. The average AOE is positive and large, indicating the inefficiency of financial markets in Pakistan.

Table 2: Descriptive statistics (PRs per share)

\begin{tabular}{lcrrr}
\hline & Mean & Median & SD & $\begin{array}{c}\text { Inter-quartile } \\
\text { range }\end{array}$ \\
\hline P & 121.690100 & 81.555000 & 133.709300 & 172.105000 \\
NOA & 106.602300 & 55.173120 & 167.679500 & 119.455600 \\
NFA & -22.158020 & -7.788727 & 92.040470 & 38.862680 \\
Net DT & -1.499455 & -1.433794 & 9.041167 & 3.775911 \\
AOE & 11.632030 & 2.364498 & 36.773870 & 23.763120 \\
\hline
\end{tabular}

Source: Authors' calculations.

Table 3 gives the per-share regression results of equation (2) in which the market value of equity is regressed on NOA, NFA, current AOE, 
LOAE, and DT. All the coefficients are significant at a 95 percent confidence interval. The coefficient of NOA is 0.32, which implies that PRe 1 of NOA is priced at PRe 0.32 by the market at a 99 percent level. NFA is valued at 0.35 of the book value, which is in line with proposition II of the Modigliani-Miller theorem. This suggests that investors view the debt acquired by KMI-30 firms positively. The coefficient of net DT is -5.63 (far below -1), which indicates that investors perceive deferred taxes negatively. The coefficient of $\mathrm{AOE}$ is positive and greater than 1 . The coefficient of LAOE is equal to 1 , which reflects persistent earnings and slow market correction.

Table 3: Pooled regression of share price $(P)$ on variables I

\begin{tabular}{lcccccc}
\hline & Coefficient & SE & T-test & P > T & 95\% confidence interval \\
\hline NFA & 0.3542 & 0.0597 & 5.9300 & 0.0000 & 0.2357 & 0.4727 \\
NOA & 0.3238 & 0.1183 & 2.7400 & 0.0070 & 0.0891 & 0.5584 \\
DT & -5.6308 & 1.2349 & -4.5600 & 0.0000 & -8.0803 & -3.1813 \\
AOE & 1.8572 & 0.2814 & 6.6000 & 0.0000 & 1.2991 & 2.4153 \\
LAOE & 1.0666 & 0.2654 & 4.0200 & 0.0000 & 0.5402 & 1.5931 \\
Intercept & 47.8195 & 11.5488 & 4.1400 & 0.0000 & 24.9126 & 70.7264 \\
\hline$R^{2}$ & & 0.5930 & & & & \\
Observations & 108 & & & & \\
\hline
\end{tabular}

Source: Authors' calculations.

We apply classification 1 (see Section 4) to equation (3) to see if investors differentiate between DTA and DTL in their valuations. Net DTA is replaced by its individual components, DTA and DTL. Table 4 employs these as two dependent variables instead of using net DTA as a collective amount. As expected, the coefficient of DTL is negative and significant at a 95 percent level.

What is interesting is that the coefficient of DTA is negative. The marginal value of PRe 1 of DTA as reported in the financials is PRs -4.98 . This could indicate that (i) investors do not associate this marginal value with DTA because the net DT amount reported is equivalent to net DTL in most cases, or (ii) it is a tax asset, but is not seen as a positive asset because, for laypersons, the probability of receiving a tax return from the government in the future is very small. 
Table 4: Pooled regression of share price (P) on variables II

\begin{tabular}{lcccccc}
\hline & Coefficient & SE & T-test & P > T & 95\% confidence interval \\
\hline NFA & 0.349 & 0.123 & 2.850 & 0.005 & 0.106 & 0.592 \\
NOA & 0.350 & 0.060 & 5.830 & 0.000 & 0.231 & 0.469 \\
AOE & 1.875 & 0.282 & 6.840 & 0.000 & 1.315 & 2.435 \\
DTL & -6.143 & 1.374 & -4.470 & 0.000 & -8.868 & -3.417 \\
DTA & -4.984 & 1.483 & -3.360 & 0.001 & -7.925 & -2.043 \\
LAOE & 1.050 & 0.266 & 3.940 & 0.000 & 0.522 & 1.578 \\
Intercept & 42.687 & 13.235 & 3.230 & 0.002 & 16.432 & 68.943 \\
\hline$R^{2}$ & & 0.5924 & & & & \\
Observations & & 108 & & & & \\
\hline
\end{tabular}

Source: Authors' calculations.

There is a large disparity in the frequency of the 35 different components of deferred tax reported in the financials. Deferred taxes arising from accelerated depreciation are recognized in 102 firm-years, provision for liabilities in 62 firm-years, staff gratuity in 37 firm-years, and unabsorbed credit and losses in 35 firm-years. Other categories occur in fewer than 18 firm-years. To see if these significantly recurring deferred tax items are value-relevant, we regress them (under classification 2 ) on the price of equity in equation (3).

Table 5 gives the per-share pooled results for equation (3) with the additional regressors of classification 2. Compared to the results of the previous regression, there is a drastic decrease in the NFA coefficient from 0.35 to 0.064 and it becomes insignificant at the 95 percent level. Almost all the recursive deferred tax components are value-relevant except provision for slow-moving items, pilferage, and bad debts. The DTL arising from accelerated depreciation is not only significant with a coefficient of -7.67 , but it also acts like a liability or negative asset class. This could be due to investors' perception that the increase in capital expenditure by the sample companies is not enough to delay these liabilities for long. This would understate the book value of the liabilities and thus overstate the book value of equity. The DTL arising from staff gratuity yields similar results.

However, the DTA arising from unabsorbed losses and credit has a negative coefficient, indicating that investors do not see these items as an asset class. They do not expect inflows to be reciprocated from these DTA, thereby overstating the book value of assets and liabilities. 
Table 5: Pooled regression of share price $(P)$ on variables III

\begin{tabular}{lcccccc}
\hline & Coefficient & \multicolumn{1}{c}{ SE } & T-test & P > T & 95\% confidence interval \\
\hline NOA & 0.371 & 0.060 & 6.160 & 0.000 & 0.252 & 0.491 \\
NFA & 0.064 & 0.150 & 0.430 & 0.669 & -0.234 & 0.363 \\
DTODT & -2.512 & 1.769 & -1.420 & 0.159 & -6.024 & 1.001 \\
DTADP & -7.673 & 1.476 & -5.200 & 0.000 & -10.604 & -4.742 \\
DTWKP & -13.207 & 12.778 & -1.030 & 0.304 & -38.571 & 12.157 \\
DTUABS & -11.414 & 2.687 & -4.250 & 0.000 & -16.747 & -6.081 \\
DTSTG & -68.842 & 31.356 & -2.200 & 0.031 & -131.083 & -6.601 \\
AOE & 2.140 & 0.291 & 7.360 & 0.000 & 1.563 & 2.718 \\
LAE & 1.217 & 0.272 & 4.480 & 0.000 & 0.677 & 1.756 \\
Intercept & 46.151 & 12.631 & 3.650 & 0.000 & 21.079 & 71.224 \\
\hline R & \multicolumn{7}{c}{0.6187} & & & & \\
Observations & 108 & & & & \\
\hline
\end{tabular}

Source: Authors' calculations.

Next, we classify net DT into the deferred tax arising from operating activities (DTOPR), financing activities (DTFIN), and investing activities (DTINV) to determine the effect of investors' perception of deferred tax items based on the activity from which they arise. Table 6 gives the results of equation (3) using classification 3. Both DTFIN and DTINV are insignificant at the 95 percent level.

To check if DTFIN and DTINV are individually equal to 0, we apply the F-test, which yields a value of 0.11 . This implies that the null cannot be rejected at the 95 percent level and thus both are equal to 0 . This could be for two reasons: (i) the relatively small number of firmyears for which these values are reported (47 and 41 firm-years in the case of DTFIN and DTINV, respectively, but 128 in the case of DTOPR), or (ii) investors do not recognize these assets or liabilities at all. On the other hand, DTOPR is negative and significant at 95 percent, which is consistent with prior results.

Table 6: Pooled regression of share price $(P)$ on variables IV

\begin{tabular}{lcccccc}
\hline & Coefficient & SE & T-test & P > T & 95\% confidence interval \\
\hline NFA & 0.307 & 0.125 & 2.460 & 0.016 & 0.059 & 0.554 \\
NOA & 0.349 & 0.062 & 5.660 & 0.000 & 0.227 & 0.472 \\
DTFIN & -4.403 & 9.445 & -0.470 & 0.642 & -23.147 & 14.341 \\
\hline
\end{tabular}




\begin{tabular}{lrrrrrr}
\hline DTINV & 0.850 & 11.762 & 0.070 & 0.943 & -22.490 & 24.191 \\
DTOPR & -5.816 & 1.285 & -4.340 & 0.000 & -8.133 & -3.031 \\
AOE & 1.839 & 0.287 & 6.400 & 0.000 & 1.269 & 2.410 \\
LAOE & 1.046 & 0.273 & 3.820 & 0.000 & 0.503 & 1.588 \\
Intercept & 50.874 & 12.847 & 3.960 & 0.000 & 25.379 & 76.369 \\
\hline $\mathrm{R}^{2}$ & 0.5825 & & & & \\
Observations & 106 & & & & \\
\hline
\end{tabular}

Source: Authors' calculations.

The results of equation (3) with the additional regressors of classification 4 are given in Table 7 . The categories include deferred tax from (i) accelerated depreciation (DTADP), (ii) deferred costs (DTDFC), (iii) revaluation (DTFV), (iv) human resource benefits (DTHR), (v) long-term investments (DTLTI), (vi) liabilities (DTLB), (vii) tax-related issues (DTTX), and (viii) working capital measurement (DTWKC). Consistent with the results reported in Table 2, the NOA coefficient is close to 0.33 and the NFA coefficient is positive, albeit slightly higher. The coefficient of current AOE is also slightly higher while that of LAOE is slightly lower.

As expected, almost all the components have a negative coefficient except for DTHR, which has a positive and insignificant coefficient. We apply the F-test to determine if all the coefficients are equal to each other and reject the null at 99 percent with an F-value of 4.79 (5.57 if DTHR is removed, given its positive coefficient). Thus, our results indicate that the coefficients of DT components vary by type; investors, in turn, react differently to different categories of deferred tax when pricing.

The coefficient of DTL arising from accelerated depreciation is consistent with the result in Table 5. Additionally, the coefficients of DTADP, DTDFC, DTTX, and DTWKC are all negative and significant, which is consistent with the finding that deferred taxes from operating activities are negative and significant (see Table 6). The DT components related to financing, such as fair-value calculations or provision for liabilities, are insignificant and thus value-irrelevant.

The coefficient of DTLTI is negative and significant; it is also larger than the other components' coefficients, indicating either a model misspecification or the possibility that the model captures information about long-term investments that NOA or AOE do not. 
Table 7: Pooled regression of share price $(\mathrm{P})$ on variables $\mathrm{V}$

\begin{tabular}{lcccccc}
\hline & Coefficient & \multicolumn{1}{c}{ SE } & T-test & P > T & 95\% confidence interval \\
\hline NFA & 0.464 & 0.161 & 2.880 & 0.005 & 0.144 & 0.784 \\
NOA & 0.332 & 0.057 & 5.800 & 0.000 & 0.218 & 0.446 \\
DTADP & -9.258 & 1.459 & -6.340 & 0.000 & -12.157 & -6.360 \\
DTDFC & -5.453 & 1.710 & -3.190 & 0.002 & -8.848 & -2.059 \\
DTFV & -0.132 & 10.492 & -0.010 & 0.990 & -20.967 & 20.702 \\
DTHR & 26.060 & 20.644 & 1.260 & 0.210 & -14.936 & 67.055 \\
DTLTI & -378.195 & 75.012 & -5.040 & 0.000 & -527.154 & -229.237 \\
DTLB & -0.369 & 10.399 & -0.040 & 0.972 & -21.019 & 20.282 \\
DTTX & -14.650 & 2.551 & -5.740 & 0.000 & -19.716 & -9.585 \\
DTWKC & -26.011 & 11.466 & -2.270 & 0.026 & -48.779 & -3.242 \\
AOE & 2.175 & 0.279 & 7.800 & 0.000 & 1.621 & 2.729 \\
LAOE & 0.804 & 0.253 & 3.180 & 0.002 & 0.302 & 1.306 \\
Intercept & 41.776 & 12.609 & 3.310 & 0.001 & 16.737 & 66.816 \\
\hline R & & 0.6755 & & & & \\
Observations & & 106 & & & & \\
\hline
\end{tabular}

Source: Authors' calculations.

Our results are not model-dependent. We have changed the model specifications by (i) including the second lag of abnormal operating income, (ii) the first lag of abnormal operating income, and (iii) deflating the dependent and independent variables by the book value of equity. All three analyses yield the same results: net DTA is value-relevant and has a negative sign. Furthermore, the deferred tax from operating activities is significant in all three specifications, the deferred tax from financing activities is never significant, and the deferred tax from investing activities is significant in specification (3). DTL is significant in all three specifications while DTA is not significant in specification (2).

\section{Conclusion}

We have used Feltham and Ohlson's (1995) theoretical framework combined with Amir et al. (1997)'s empirical work to test whether deferred taxes are value-relevant in Pakistan. Our model identifies the market price of equity as a function of NOA, NFA, net DT, and current and lagged AOE. Based on a sample drawn from firms listed on the KMI-30 index from 2010 to 2013, we find that NFA and NOA are value-relevant. Investors do not consider firms to have created any value addition when these asset classes 
grow, as a result of which they are heavily discounted. The current and lagged $\mathrm{AOE}$ are also significant, indicating the persistence of earnings.

Net DTA are value-relevant although their coefficients are negative, implying that investors treat them as liabilities rather than assets. Even though both net DTA and NFA are negative for most companies, investors perceive net DTA as a source of value destruction and NFA as a source of value addition. Both DTA and DTL are value-relevant: DTA are treated as a source of value destruction and DTL as real liabilities. We also find that only the deferred taxes arising from operating activities are treated as value-relevant by the market; those arising from financing and investing are value-irrelevant.

Our results suggest that different components of DTA are valuerelevant. The DTL from accelerated depreciation are significant but negative, indicating that investors treat them as liabilities that will reverse in the short term. Other categories that are value-relevant, albeit negative, include DTA arising from deferred costs, long-term investments, taxes, and changes in working capital. This suggests that investors do not associate these categories with a positive cash flow in the future. Moreover, they perceive firms that have paid more tax in a negative light.

These findings suggest that Pakistani investors treat both DTA and DTL negatively, penalizing companies that attempt to manage their earnings through the use of deferred taxes. Firms' deferred tax disclosures often contain numerous terms that are neither self-explanatory nor explained adequately in their financials, thus becoming cause for concern among laypersons and novice investors. For most investors, taxes have a negative connotation because there is little faith in the system, and deferred taxesseen as the excess payment of taxes-are perceived as a source of value destruction. What investors do not take into account is that this is simply a notional exercise, given that taxes cannot be "deferred" in the literal sense.

We recommend that the tax authorities streamline the terminology used for deferred tax components and explain book-tax nonconformity to investors in terms of deferred tax along with each firm's disclosure notes. 


\section{References}

Amir, E., Kirschenheiter, M., \& Willard, K. (1997). The valuation of deferred taxes. Contemporary Accounting Research, 14(4), 597-622.

Amir, E., \& Sougiannis, T. (1999). Analysts' interpretation and investors' valuation of tax carry-forwards. Contemporary Accounting Research, 16(1), 1-33.

Beechy, T. H. (1983). Accounting for corporate income taxes: Conceptual considerations and empirical analysis. Toronto, ON: Canadian Institute of Chartered Accountants.

Brown, J. L., Drake, K. D., \& Martin, M. (2013). Are firms myopic? The case of contracting on performance and risk (Mimeo). Retrieved from http://papers.ssrn.com/sol3/papers.cfm?abstract_id=1659439\#\#

Carnahan, I., \& Novack, J. (2002). Two birds, one stone: Would firms inflate their earnings if it meant more taxes? Forbes, 169(5), 40.

Chambers, R. J. (1968). Tax allocation and financial reporting. Abacus, 4(2), 99-123.

Chen, K., \& Schoderbek, M. (2000). The 1993 tax rate increase and deferred tax adjustments: A test of functional fixation. Journal of Accounting Research, 38(1), 23-44.

Chludek, A. K. (2011). Perceived versus actual cash flow implications of deferred taxes: An analysis of value relevance and reversal under IFRS. Journal of International Accounting Research, 10(1), 1-25.

Davidson, S. (1958). Accelerated depreciation and the allocation of income taxes. The Accounting Review, 33, 173-180.

European Financial Reporting Advisory Group. (n.d.). Proactive Financial reporting for corporate income taxes [Webpage]. Retrieved 28 May 2014, from http://www.efrag.org/Front/p177-2272/Proactive---Financial-Reporting-for-Corporate-IncomeTaxes.aspx

Feltham, G., \& Ohlson, J. (1995). Valuation and clean surplus accounting for operating and financial activities. Contemporary Accounting Research, 11(2), 689-731. 
Givoly, D., \& Hayn, C. (1992). The valuation of the deferred tax liability: Evidence from the stock market. The Accounting Review, 67(2), 394410.

Guenther, D., \& Sansing, R. (2000). Valuation of the firm in the presence of temporary book-tax differences: The role of deferred tax assets and liabilities. The Accounting Review, 75(1), 1-12.

Hanlon, M. (2005). The persistence and pricing of earnings, accruals, and cash flows when firms have large book-tax differences. The Accounting Review, 80(1), 137-166.

Hanlon, M., \& Heitzman, S. (2010). A review of tax research. Journal of Accounting and Economics, 50(2), 127-178.

Hanlon, M., \& Slemrod, J. (2009). What does tax aggressiveness signal? Evidence from stock price reactions to news about tax shelter involvement. Journal of Public Economics, 93, 126-141.

IFRS Foundation. (n.d.). The unaccompanied IASs and their technical summaries [Webpage]. Retrieved 28 May 2014, from http://www.ifrs.org/IFRSs/Pages/IAS.aspx

Joos, P., Pratt, P., \& Young, S. D. (2002). Using deferred taxes to infer the quality of accruals (Mimeo). INSEAD, Paris, and Massachusetts Institute of Technology, Cambridge, MA.

Lev, B., \& Nissim, D. (2004). Taxable income, future earnings, and equity values. The Accounting Review, 79(4), 1039-1074.

Livingstone, J. L. (1967). Accelerated depreciation, cyclical asset expenditures and deferred taxes. Journal of Accounting Research, 5(1), 77-94.

Narasimhan, M. S., \& Harisha, B. V. (2006). Impact of deferred tax facility on firm value. The Chartered Accountant, 55(1), 56-63.

Phillips, J., Pincus, M., \& Rego, S. (2003). Earnings management: New evidence based on deferred tax expense. The Accounting Review, 78(2), 491-521. 
Poterba, J., Rao, N., \& Seidman, J. (2007). The significance and composition of deferred tax assets and liabilities (Working Paper No. 12923). Cambridge, MA: National Bureau of Economic Research.

Sansing, R. (1998). Valuing the deferred tax liability. Journal of Accounting Research, 36(2), 357-364.

Sansing, R., \& Guenther, D. (2003). The valuation relevance of reversing deferred tax liabilities (Working Paper No. 03-24). Hanover, NH: Tuck School of Business.

Schmidt, A. P. (2006). The persistence, forecasting, and valuation implications for the tax change component of earnings. The Accounting Review, 81(3), 589-616.

Stickney, C. P. (1993). Financial statement analysis: A strategic perspective ( $2^{\text {nd }}$ ed.). Fort Worth, TX: Dryden Press.

Wolk, H. I., Tearney, M. G., \& Dodd, J. L. (2001). Accounting theory: A conceptual and institutional approach (5 $5^{\text {th }}$ ed.). Cincinnati, $\mathrm{OH}$ : South-Western College Publishing.

Wong, J., Wong, N., \& Naiker, V. (2011). Comprehensive versus partial deferred tax liabilities and equity market values. Accounting and Finance, 51(4), 1087-1106. 


\section{Appendix}

Classification of deferred tax assets/liabilities as per classification 4

\begin{tabular}{|c|c|c|}
\hline & Component & Classification 4 \\
\hline 1 & Accelerated depreciation & $\begin{array}{l}\text { Accelerated } \\
\text { depreciation }\end{array}$ \\
\hline 2 & Exploration expenditure & Deferred cost \\
\hline 3 & Exploratory wells costs & Deferred cost \\
\hline 4 & Prospecting and development expenditure & Deferred cost \\
\hline 5 & Share issuance cost, net to equity & Deferred cost \\
\hline 6 & Fair value of hedging instruments & Revaluation \\
\hline 7 & Investments at fair value through profit and loss & Revaluation \\
\hline 8 & Re-measurement of investment available for sale & Revaluation \\
\hline 9 & Revaluation of property, plant, and equipment & Revaluation \\
\hline 10 & Unamortized balance of loans at fair value & Revaluation \\
\hline 11 & Provision for compensated absences & Human resource \\
\hline 12 & Staff retirement benefits, gratuity & Human resource \\
\hline 13 & Provision for Workers Welfare Fund & Human resource \\
\hline 14 & Share of profit (loss) on associates & Long-term investments \\
\hline 15 & Investment in associates & Long-term investments \\
\hline 16 & Long-term receivables & Long-term investments \\
\hline 17 & Net borrowing cost capitalized & Long-term investments \\
\hline 18 & Assets subject to finance lease & Provision for liabilities \\
\hline 19 & Derivative financial instruments, net to equity & Provision for liabilities \\
\hline 20 & Interest payable on security deposits & Provision for liabilities \\
\hline 21 & Liabilities against assets subject to finance lease & Provision for liabilities \\
\hline 22 & Liabilities offered for taxation & Provision for liabilities \\
\hline 23 & $\begin{array}{l}\text { Preference shares/convertibles stock transaction } \\
\text { cost-liability portion }\end{array}$ & Provision for liabilities \\
\hline 24 & Provision for decommissioning obligations & Provision for liabilities \\
\hline 25 & Unpaid trading liabilities & Provision for liabilities \\
\hline 26 & $\begin{array}{l}\text { Unrealized exchange losses on foreign currency } \\
\text { loans }\end{array}$ & Provision for liabilities \\
\hline 27 & Provision for excise, taxes, and other duties & Tax-related \\
\hline 28 & Final tax regime & Tax-related \\
\hline 29 & Minimum tax adjustment & Tax-related \\
\hline 30 & Provision for tax amortization & Tax-related \\
\hline
\end{tabular}


Earnings Management Through Deferred Taxes Recognized Under IAS 12: 19 Evidence From Pakistan

\begin{tabular}{lll}
\hline \multicolumn{1}{c}{ Component } & \multicolumn{1}{c}{ Classification $\mathbf{4}$} \\
\hline 31 & Sales tax refundable & Tax-related \\
32 & Tax on fair value adjustments & Tax-related \\
33 & Tax on subsidiary reserves & Tax-related \\
34 & Unabsorbed tax losses/credits & Tax-related \\
35 & Other & Working capital \\
36 & Provision for slow-moving spares, store & Working capital \\
& obsolescence, doubtful debts, other receivables, etc. & \\
37 & Short-term provisions & Working capital \\
\hline
\end{tabular}

